Vol. 4 , No. 1 Februari 2019

\title{
GAMBARAN KESIAPAN TENAGA KESEHATAN DALAM MANAJEMEN BENCANA DI PUSKESMAS WILAYAH RAWAN BENCANA
}

\section{(Description Preparedness of Health Workers in Disaster Management in Public Health Center Disaster Vulnerable Area)}

\section{Arsi Susilawati, Ferry Efendi and Setho Hadisuyatmana}

Fakultas Keperawatan, Universitas Airlangga, Surabaya, Indonesia

\section{RIWAYAT ARTIKEL}

Diterima: 2 Desember 2018

Disetujui: 8 Februari 2019

\section{KONTAK PENULIS}

Arsi Susilowati

arsi.susilawati-2017@fkp.unair.ac.id Fakultas Keperawatan, Universitas Airlangga

\begin{abstract}
ABSTRAK
Pendahuluan: Manajemen bencana merupakan faktor yang sangat penting untuk mengurangi dampak dari kejadian bencana. Sejauh ini, kesiapan tenaga kesehatan dalam manajemen bencana di puskesmas rawan bencana di kabupaten Sumbawa Barat belum pernah dievaluasi. Penelitian ini bermaksud mengeksplorasi faktor sosiodemografi serta menggambarkan kesiapan tenaga kesehatan dalam manajemen bencana.
\end{abstract}

Metode: Penelitian ini menggunakan desain cross sectional. Populasi penelitian ini adalah tenaga kesehatan yaitu dokter, perawat, dan bidan di puskesmas di Kabupaten Sumbawa Barat. Besar sampel adalah 211 sampel yang dipilih random di 9 puskesmas, dengan cara mengambil kertas yang berisi nomor urut sesuai dengan daftar nama tenaga kesehatan di setiap puskesmas. Variabel dependen adalah pengetahuan dalam manajemen bencana, sedangkan variabel independen adalah faktor sosiodemografi. Data dikumpulkan menggunakan kuisioner elektronik KAP DM Questionnaire yang mencakup 7 pertanyaan terkait data sosiodemografi dan 17 pertanyaan terkait pengetahuan tentang manajemen bencana. Data kemudian dianalisis menggunakan uji statistik Chi-Square.

Hasil: Sebagian besar tenaga kesehatan memiliki pengetahuan yang baik dalam manajemen bencana. Diantara faktor sosiodemografi yang dipelajari, tingkat pendidikan, tempat bekerja, dan pengalaman terlibat dalam kegiatan tanggap darurat bencana secara signifikan berhubungan dengan pengetahuan dalam manajemen bencana.

Kesimpulan: Dengan keragaman latar belakang, responden menunjukkan pengetahuan yang baik. Peningkatan pendidikan terkait manajemen bencana dan peningkatan kapasitas tempat bekerja perlu ditingkatkan untuk memperbaiki pengetahuan tenaga kesehatan di puskesmas.

\section{Kata Kunci}

manajemen bencana, Tenaga kesehatan, kesiapan

\section{ABSTRACT}

Introduction: Disaster management is a very important factor in reducing the impact of a disaster. So far, the readiness of health workers in disaster management in disaster-prone health centers in West Sumbawa district has never been evaluated. This study intends to explore sociodemographic factors and illustrate the readiness of health workers in disaster management.

Method: This study used a cross-sectional design. The population of this study is health workers, namely doctors, nurses, and midwives in health centers in West Sumbawa Regency. The sample size was 211 samples (doctors, nurses, midwives) who were randomly selected in 9 health centers, by taking paper containing the serial number according to the list of names of health workers in each PHC. The dependent variable is knowledge in disaster management, while the independent variable is a sociodemographic factor. Data were collected using an electronic questionnaire that included seven questions related to sociodemographic data and 17 questions related 
Kutip sebagai:

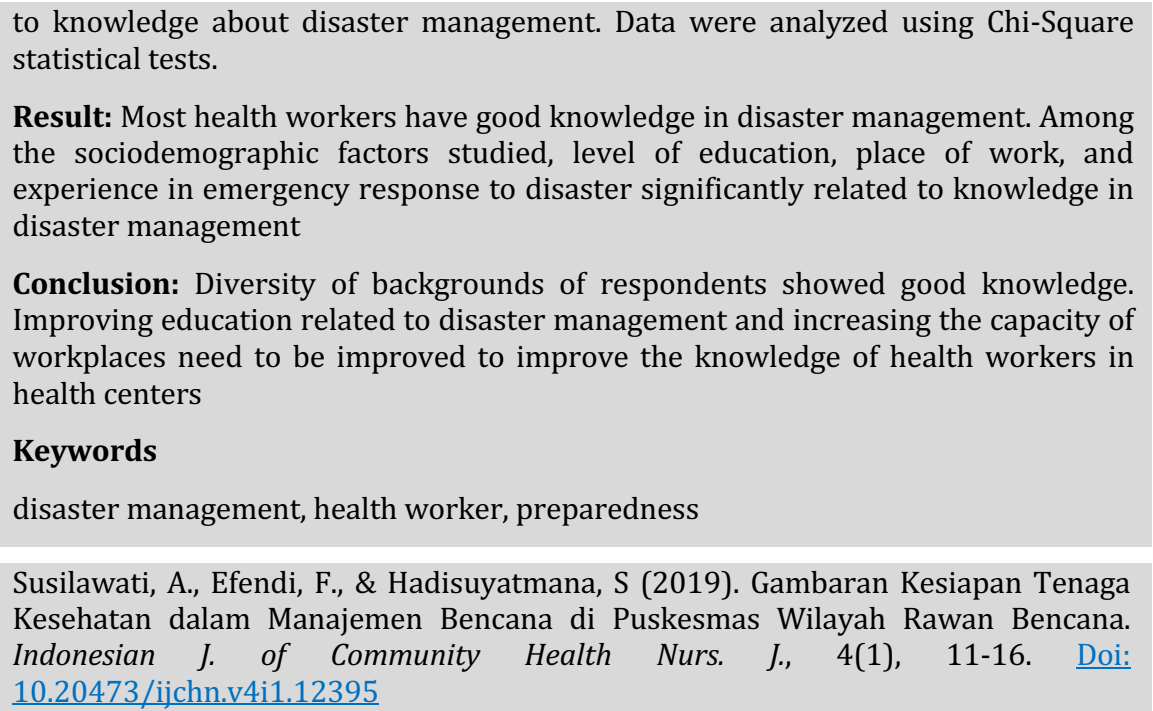

\section{PENDAHULUAN}

Pelayanan kesehatan pada saat bencana merupakan faktor yang sangat penting untuk mencegah terjadinya kematian, kecacatan dan kejadian penyakit, serta mengurangi dampak yang ditimbulkan akibat bencana yang merupakan suatu kejadian yang tidak diinginkan dan biasanya terjadi secara mendadak serta menimbulkan korban jiwa (Menteri Kesehatan RI, 2006). Salah satu kendala yang sering dijumpai dalam penanggulangan krisis di daerah bencana adalah kurangnya Sumber Daya Manusia (SDM) Kesehatan yang dapat difungsikan baik dari segi jumlah dan jenis serta kompetensinya (Menteri Kesehatan RI, 2006). Menurut Kepmenkes Nomor 066/MENKES/SK/II/2006 tentang Pedoman Manajemen SDM Kesehatan Dalam Penanggulangan Bencana, perencanaan penempatan SDM kesehatan untuk pelayanan kesehatan pada kejadian bencana sangat perlu untuk memperhatikan kompetensi manajemen bencana yang dimiliki SDM kesehatan setempat khususnya yang bertugas di Pusat Kesehatan Masyarakat (Puskesmas), terutama di daerah rawan bencana. Berdasarkan data Indeks Risiko Bencana Indonesia (IRBI) Tahun 2013, Kabupaten Sumbawa Barat yaitu salah satu kabupaten yang terdampak kejadian bencana tersebut merupakan wilayah dengan resiko tinggi terhadap bencana gempa bumi (BNPB, 2015b). Untuk dapat meminimalisir kerugian akibat bencana yang terjadi, peran tenaga kesehatan yang tanggap dan siap sangat diperlukan (Tatuil, Mandagi and Engkeng, 2015). Namun sejauh ini, tingkat kesiapan dan kompetensi manajemen bencana tenaga kesehatan yang bekerja di puskesmas di Kabupaten Sumbawa Barat belum pernah dievaluasi.

Indonesia merupakan salah satu negara paling rawan bencana di dunia, seringkali dan tidak terduga, yaitu di antaranya gempa bumi, tsunami, tanah longsor, letusan gunung berapi, banjir, dan kekeringan (CFE-DM, 2018). Badan Nasional Penanggulangan Bencana (BNPB) mencatat pada
2017 terjadi 2.862 kejadian bencana alam, diantaranya banjir $(34,2 \%)$, puting beliung (31\%), tanah longsor $(29,6 \%)$, kebakaran hutan dan lahan $(3,4 \%)$, gempa bumi $(0,7 \%)$, kekeringan $(0,6 \%)$, gelombang pasang/abrasi $(0,4 \%)$, dan letusan gunung api $(0,1 \%)$ (BNPB, 2018).

Nusa Tenggara Barat (NTB), merupakan salah satu provinsi yang sering mengalami ancaman bencana alam. BNPB mencatat pada 2017, provinsi ini mengalami sebanyak 71 kejadian bencana alam, diantaranya banjir (41), puting beliung (14), kekeringan (9), tanah longsor (6), dan kebakaran hutan dan lahan (1) (BNPB, 2018b). Dampaknya, tercatat 10 orang korban meninggal dunia, 8 orang korban luka-luka dan 903.277 orang mengungsi (BNPB, 2018b). Secara materiil, kejadian tersebut mengakibatkan 92 rumah rusak berat, 167 rumah rusak sedang, 948 rumah rusak ringan, 8.599 rumah terendam banjir dan 31 fasilitas umum dan sosial mengalami kerusakan (BNPB, 2018b). Setahun berikutnya, 29 Juli 2018, terjadi gempa bumi di NTB, yang disusul oleh rangkaian gempa susulan di sepanjang bulan Agustus 2018, mengakibatkan korban jiwa dan materiil. Hingga tanggal 21 Agustus 2018, BNPB (2018) mencatat 515 orang meninggal dunia dan 7.145 orang korban luka-luka dan 431.416 orang mengungsi. Secara materiil, bencana tersebut mengakibatkan 73.843 rumah dan 798 fasilitas umum dan sosial rusak.

Pusat Kesehatan Masyarakat (Puskesmas) memiliki peran aktif dalam meningkatkan

keterlibatan masyarakat dalam upaya penanggulangan bencana sebagai unit pelayanan kesehatan terdekat di masyarakat (BNPB, 2015b). Puskesmas bertugas untuk memberikan pelayanan kesehatan saat krisis bencana dengan melakukan berbagai kegiatan seperti: pelayanan gawat darurat 24 jam, pendirian pos kesehatan 24 jam di sekitar lokasi bencana, upaya gizi, Kesehatan Ibu dan Anak (KIA) dan sanitasi pengungsian, upaya kesehatan jiwa serta upaya kesehatan rujukan sesaat setelah terjadinya bencana (DEPKES, 2007). Karenanya 
tenaga kesehatan di puskesmas memiliki peran untuk mempersiapkan kelompok rentan pada fase akut bencana (Tatuil, Mandagi and Engkeng, 2015). Mereka perlu untuk membekali diri dengan skill manajemen bencana yang baik (Tatuil, Mandagi, \& Engkeng, 2015). Hasil studi pendahuluan mengindikasikan bahwa tenaga kesehatan yang bekerja di Puskesmas Poto Tano, Kabupaten Sumbawa Barat belum pernah mendapatkan pelatihan dan manajemen tanggap bencana. Beberapa di antara mereka menyatakan belum mengetahui tentang manajemen bencana ataupun terlibat langsung dalam penanganan bencana. Hal ini menunjukkan bahwa kesiapan tenaga kesehatan dalam menghadapi potensi bencana di Kabupaten Sumbawa Barat masih diragukan.

Penelitian sebelumnya menjelaskan bahwa lemahnya kompetensi profesional telah menyebabkan tenaga kesehatan gagal untuk berperan saat bencana (Tatuil, Mandagi and Engkeng, 2015). Dalam penelitian ini bermaksud mengidentifikasi sosiodemografi tenaga kesehatan di puskesmas serta menggambarkan pengetahuan tenaga kesehatan dalam manajemen bencana di Puskesmas wilayah rawan bencana di Kabupaten Sumbawa Barat.

\section{METODE}

Penelitian ini merupakan penelitian kuantitatif dengan menggunakan pendekatan cross sectional. Populasi adalah tenaga kesehatan (dokter, perawat, dan bidan) yang bertugas di 9 Puskesmas di wilayah kerja Dinas Kesehatan Kabupaten Sumbawa Barat. Jumlah sampel adalah 211 responden yang dipilih secara cluster sampling. Kemudian responden dipilih random sehingga setiap tenaga kesehatan di tiap puskesmas lokasi penelitian memiliki kemungkinan dan kesempatan yang sama untuk menjadi responden. Setelah mendapat persetujuan dari 211 responden terpilih, kemudian dilanjutkan dengan pengisian kuisioner pada halaman G-form yang berisi penjelasan penelitian, informed consent, dan formulir kuisioner yang mencakup 7 pertanyaan data sosiodemografi dan 17 pertanyaan pengetahuan tentang manajemen bencana. Variabel independen dalam penelitian ini adalah latar belakang sosiodemografi tenaga kesehatan. Kemudian variabel dependen penelitian ini antara lain pengetahuan dalam manajemen bencana.

Penelitian ini menggunakan uji analisis statistik ChiSquare dengan $\mathrm{p}$ value $<0,05$. Untuk penelitian ini, instrumen yang digunakan untuk mengumpulkan data studi adalah KAP DM Questionnaire yaitu kuisioner yang dikembangkan oleh Nurul'Ain Ahayalimudin (2012) pada penelitiannya yang berjudul "Disaster Management: A Study on Knowledge, Attitude and Practices of Emergency Nurses and Community Health Nurses in Selangor". Kuisioner tersebut digunakan untuk mengeksplorasi pengetahuan, sikap, dan praktik pada staf perawat, dokter dan asisten petugas medis dalam penanggulangan bencana. Penggunaan instrumen penelitian ini telah mendapatkan izin dari Nurul'Ain Ahayalimudin sebagai peneliti sebelumnya. Kuesioner yang digunakan dalam penelitian ini memiliki dua domain: data sosiodemografi yang berisi 7 pertanyaan, dan pengetahuan yang berisi 17 pertanyaan tentang manajemen bencana.

Hasil uji etik di KEPK Fakultas Keperawatan UNAIR adalah dengan nomor sertifikat etik No. 1228-KEPK.

\section{HASIL}

Tabel 1. Data Sosiodemografi Tenaga Responden

\begin{tabular}{|c|c|c|}
\hline Karakteristik Responden & n & $\%$ \\
\hline \multicolumn{3}{|l|}{ Usia } \\
\hline$<25$ Thn & 41 & 19.4 \\
\hline 26-35 Thn & 134 & 63.5 \\
\hline 36-45 Thn & 32 & 15.2 \\
\hline 46-55 Thn & 3 & 1.4 \\
\hline 56-65 Thn & 1 & 0.5 \\
\hline \multicolumn{3}{|l|}{ Jenis kelamin } \\
\hline Laki-laki & 48 & 22.7 \\
\hline Perempuan & 163 & 77.3 \\
\hline \multicolumn{3}{|l|}{ Tk. Pendidikan } \\
\hline SPK & 4 & 1.9 \\
\hline Diploma & 132 & 62.6 \\
\hline Sarjana & 75 & 35.5 \\
\hline \multicolumn{3}{|l|}{ Tempat Bekerja } \\
\hline PKM Poto Tano & 27 & 12.8 \\
\hline PKM Seteluk & 36 & 17.1 \\
\hline PKM Taliwang & 42 & 19.9 \\
\hline PKM Brang Ene & 15 & 7.1 \\
\hline PKM Brang Rea & 27 & 12.8 \\
\hline PKM Jereweh & 19 & 9 \\
\hline PKM Maluk & 19 & 9 \\
\hline PKM Sekongkang & 14 & 6.6 \\
\hline PKM Tongo & 12 & 5.7 \\
\hline \multicolumn{3}{|l|}{ Lama Bertugas } \\
\hline$<1$ Thn & 27 & 12.8 \\
\hline 1-5 Thn & 88 & 41.7 \\
\hline 6-10 Thn & 64 & 30.3 \\
\hline >10 Thn & 32 & 15.2 \\
\hline \multicolumn{3}{|l|}{ Pernah Terlibat Dalam } \\
\hline \multicolumn{3}{|l|}{ Kegiatan Tanggap Darurat } \\
\hline \multicolumn{3}{|l|}{ Bencana } \\
\hline Ya & 122 & 57.8 \\
\hline Tidak & 89 & 42.2 \\
\hline \multicolumn{3}{|l|}{ Pernah Pelatihan Tentang } \\
\hline \multicolumn{3}{|l|}{ Manajemen Bencana } \\
\hline $\mathrm{Ya}$ & 48 & 22.7 \\
\hline Tidak & 163 & 77.3 \\
\hline \multicolumn{3}{|l|}{ Termasuk Dalam Tim Gerak } \\
\hline \multicolumn{3}{|l|}{ Cepat (TGC) di Puskesmas } \\
\hline Ya & 56 & 26.5 \\
\hline Tidak & 155 & 73.5 \\
\hline Total & 211 & 100 \\
\hline
\end{tabular}


Tabel 2. Distribusi Variabel Dependen Pengetahuan Tenaga Kesehatan Dalam Manajemen Bencana

\begin{tabular}{lcc}
\hline \multicolumn{1}{c}{ Pengetahuan } & n & \% \\
\hline Baik & 141 & 66.8 \\
Cukup & 59 & 28 \\
Kurang & 11 & 5.2 \\
Total & 211 & 100 \\
\hline
\end{tabular}

Dilihat dari tabel 1 menunjukan Secara umum, sebagian besar responden penelitian ini berusia 2635 tahun $(63,5 \%)$ dengan tendensi jenis kelamin perempuan yang lebih banyak (77,3\%) dibandingkan responden laki-laki, tingkat pendidikan tertinggi responden Diploma $3(62,6 \%)$, masa kerja kurang dari lima tahun $(54,5 \%)$, pernah terlibat dalam kegiatan tanggap darurat bencana $(57,8 \%)$, tidak pernah berpartisipasi sebagai peserta pelatihan manajemen bencana $(77,3 \%)$, dan tidak termasuk dalam Tim Gerak Cepat bencana di institusi kerjanya $(73,5 \%)$.

Dilihat dari tabel 2 menunjukan bahwa responden penelitian ini sebagian besar memiliki pengetahuan yang baik tentang manajemen bencana. Hanya sebagian kecil di antaranya yang memiliki kekurangan dalam pemahaman manajemen bencana tersebut. Didapatkan hasil uji statistik Chi-Square dengan nilai signifikan $p>$ 0,05 yang menjelaskan bahwa umur dan pengetahuan responden tidak memiliki hubungan yang signifikan. Dominasi responden berjenis kelamin perempuan menjelaskan mengapa mayoritas responden perempuan memiliki pengatahuan yang lebih baik jika dibandingkan pada responden laki-laki. Namun, uji statistik pada penelitian ini menunjukkan tidak adanya hubungan antara jenis kelamin dengan pengetahuan responden.

Berdasarkan karakteristik jenjang pendidikan terakhir, responden berlatar SPK memiliki pengetahuan yang baik, dan responden berlatar Diploma dan Sarjana sebagian besar memiliki pengetahuan baik. Pada subvariabel tempat bekerja dan pengetahuan tenaga kesehatan, penelitian menunjukkan bahwa tenaga kerja yang bekerja di lokasi akses informasi, sarana prasarana, dan fasilitas penunjang kerja yang baik memiliki pengetahuan yang memadai tentang manajemen bencana. Hubungan ini dikuatkan dengan nilai $\mathrm{p}<0,05$ yang menjelaskan bahwa tempat bekerja dan pengetahuan responden memiliki hubungan yang signifikan.

Pada subvariabel lama bekerja, kepesertaan responden dalam pelatihan sebelumnya, dan keterlibatan responden dalam Tim Gerak Cepat (TGC) tidak menunjukkan adanya hubungan dengan pengetahuannya. Asumsi peneliti, hal tersebut dimungkinkan karena tenaga kesehatan yang termasuk dalam TGC di puskesmas di kabupaten Sumbawa Barat tidak dibekali dengan pengetahuan yang memadai dan di pilih tidak berdasarkan kompetensi yang dimilikinya. Hal tersebut juga karena upaya peningkatan kompetensi untuk tenaga kesehatan di puskesmas dalam menghadapi situasi bencana belum optimal.

\section{PEMBAHASAN}

Hasil penelitian menunjukkan bahwa sebagian besar tenaga kesehatan (dokter, perawat, dan bidan) memiliki pengetahuan yang baik tentang manajemen bencana, khususnya terkait pengertiannya, dan upayaupaya yang dilakukan di setiap fasenya, walaupun sebagian besarnya masih salah dalam membedakan klasifikasi bencana alam, non alam daan bencana sosial. Di beberapa penelitian sejenisnya yang dilakukan pada tenaga kesehatan yaitu perawat menunjukkan bahwa hasil ini tidak sejalan dengan penelitian Hermawati (2010), yang menunjukkan bahwa perawat memiliki tingkat pengetahuan tentang bencana yang lebih rendah. Demikian pula, hasil studi Hammad et al (2011) yang menyimpulkan bahwa perawat memiliki pengetahuan kebencanan yang kurang. Menurut asumsi peneliti, peningkatan teknologi informasi melalui internet mempengaruhi pengetahuan umum responden terkait manajemen bencana, sehingga walaupun sebagian besar responden tidak pernah mengikuti pelatihan tentang manajemen bencana, responden sudah mengetahui tentang dasar-dasar pengetahuan yang harus diketahui tenaga kesehatan dalam manajemen bencana. Salah satu contohnya adalah ketersediaan informasi dari Kementerian Komunikasi dan Informatika (Kemenkominfo) RI tentang berbagai informasi terbaru terkait penanganan bencana yang terjadi di Indonesia yang dapat diakses dengan mudah melalui situs internet. Hal ini merupakan bentuk perkembangan kondisi telekomunikasi untuk penanganan bencana di Indonesia yang tentunya sangat bermanfaat terutama dalam menghadapi situasi krisis saat bencana terjadi.

\section{Hubungan antara tingkat pendidikan dengan pengetahuan}

Penelitian ini membuktikan adanya hubungan antara tingkat pendidikan responden dengan pengetahuan yang dimiliki. Sebagaimana pendapat Osman (2016) yang menyatakan adanya hubungan signifikan antara tingkat pendidikan responden dengan pengetahuannya tentang manajemen bencana. Hasil ini menjelaskan bahwa semakin tinggi pendidikan responden maka semakin baik pula pengetahuan tentang manajemen bencana.

Pengetahuan yang baik akan menentukan keberhasilan dalam manajemen bencana. Sumber daya kesehatan sangat berpengaruh pada kesiapsiagaan bencana karena ketiadaan pakar kesehatan akan menjadi faaktor penghalang dalam menangani situasi darurat (Depkes RI, 2007). Dalam peningkatan kompetensi tenaga kesehatan, hasil penelitian ini menjadi dasar rekomendasi bagi pemerintah daerah setempat untuk mengupayakan dukungan dan membuka kesempatan seluas-luasnya bagi tenaga kesehatan untuk mendapatkan pelatihan-pelatihan terkait manajemen bencana melalui pendidikan formal dan non formal. Penelitian ini juga merekomendasikan kebutuhan manajemen bencana ke dalam kurikulum pendidikan formal bagi tenaga kesehatan. Pembahasan ini dapat dimasukkan ke 
dalam kurikulum pendidikan keperawatan atau pendidikan profesi kesehatan lainnya sebagai kompetensi tenaga kesehatan di Indonesia, khususnya bagi mereka yang akan bekerja di daerah rawan bencana.

\section{Hubungan antara tempat bekerja dengan pengetahuan}

Hasil penelitian ini menunjukkan adanya hubungan yang bermakna antara tempat bekerja responden dengan pengetahuan yang dimiliki. Hal ini tidak sejalan dengan penelitian sebelumnya yang dilakukan Ahayalimuddin (2012) yang menyatakan tidak adanya hubungan signifikan antara tempat bekerja dengan pengetahuan yang dimiliki responden tentang manajemen bencana. Menurut pendapat peneliti, hal ini berkenaan dengan ketersediaan fasilitas kesehatan, sarana dan prasarana pendukung, akses informasi, dan kompetensi sumber daya kesehatan.

Opini ini didukung oleh data penelitian yng menunjukkan bahwa lokasi penelitian yang memiliki skor terbaik pada komponen pengetahuan dan praktik tenaga kesehatan berada di kawasan perkotaan. Seperti contohnya Puskesmas Maluk dan Puskesmas Taliwang yang berada di daerah industri berkembang dan pusat pemerintahan Kabupaten. Puskesmas Maluk secara rutin mendapatkan bantuan dana kompensasi pengembangan industri pertambangan, CSR industri swasta dan pendapatan daerah yang dapat dimanfaatkan untuk pengembangan sarana dan prasarana pendukung pelayanan kesehatan, termasuk dalam upaya peningkatan kompetensi tenaga kesehatan yang bertugas di daerah setempat.

\section{Hubungan antara pernah terlibat kegiatan tanggap darurat bencana dengan pengetahuan} Hasil penelitian ini mengindikasikan adanya pengalaman keterlibatan responden dalam kegiatan tanggap bencana sebelumnya memberikan kontribusi terhadap pengetahuan tenaga kesehatan tentang manajemen bencana. Hal ini sejalan dengan pendapat Osman (2016) yang menyatakan adanya hubungan signifikan antara keterlibatan responden dalam penanggulangan bencana sebelumnya dengan pengetahuannya tentang bencana. Hasil ini menjelaskan bahwa pengalaman individu terkait keterlibatan dalam penanggulangan bencana akan seiring dengan pengetahuan tentang manajemen bencana. Dapat disimpulkan bahwa pengalaman yang dilakukan dapat digunakan dan menjadi pedoman serta pembelajaran bagi tenaga kesehatan untuk meningkatkan pengetahuan. Dengan pengalaman yang didapat seseorang akan lebih cakap dan terampil serta mampu melaksanakan tugas pekerjaannya. Latihan berulang-ulang akan memperkuat dan meningkatkan pengetahuan dan kemampuan seseorang. Pengalaman menjadi proses pembelajaran yang paling baik bagi seseorang untuk mempelajari segala hal secara langsung, dimana pemahamannya akan situasi kondisi yang pernah dialami, dijalani dan dilakukan pasti akan lebih baik daripada jika dipelajari secaara teori, hal tersebut tentunya akan menjadi gambaran yang lebih riil bagi yang bersangkutan guna meningkatkan pengetahuannya. Menjadi hal yang wajar jika keterlibatan seorang tenaga kesehatan dalam penanggulangan bencana dapat mempengaruhi pengetahuannya tentang manajemen bencana yang tentunya menjadi lebih tahu. Sumber daya kesehatan yang kompeten, tanggap, cakap, dan terampil dibutuhkan dalam menghadapi situasi krisis, menangani kesiapsiagaan bencana, untuk mewujudkan sumber daya manusia yang terlatih maka diperlukan adanya pelatihan kegawatdaruratan dan kebencanaan bagi setiap individu.

\section{KESIMPULAN}

Gambaran pengetahuan tenaga kesehatan tentang manajemen bencana di puskesmas wilayah rawan bencana di Kabupaten Sumbawa Barat sebagian besar termasuk pada kategori baik. Tingkat pendidikan, tempat bekerja, dan pernah terlibat dalam kegiatan tanggap darurat bencana secara signifikan berhubungan dengan pengetahuan tenaga kesehatan di puskesmas tentang manajemen bencana. di puskesmas agar lebih meningkatkan pengetahuan dan keterampilan tentang kesiapsiagaan bencana dengan mengikuti pelatihan kebencanaan dan kegawatdaruratan secara kontinue dalam rangka menunjang kesiapan dalam memberikan pelayanan kesehatan yang cepat, tanggap, sigap dan tepat saat menghadapi situasi krisis bencana.

Pemantauan kesiapan tenaga kesehatan dalam manajemen bencana dapat dilakukan secara berkala oleh Dinas Kesehatan, dimana hasilnya dapat menjadi rekomendasi untuk peningkatan kompetensi tenaga kesehatan yang ada, peningkatan sarana dan prasarana serta akses informasi di bidang kesehatan dan penanggulangan bencana. Diperlukan adanya tim yang terlatih untuk menangani kesiapsiagaan bencana, untuk mewujudkan sumber daya manusia yang terlatih maka diperlukan adanya pelatihan kegawatdaruratan dan kebencanaan bagi setiap individu terutama tenaga kesehatan di puskesmas. Penelitian ini dapat dijadikan sebagai acuan dan wawasan informasi untuk bisa dikembangkan lebih lanjut dalam bentuk metode atau desain penelitian lainnya dengan jumlah sampel yang lebih banyak sehingga hasilnya dapat dijadikan bahan referensi untuk penelitian lanjutan menyangkut faktorfaktor yang mempengaruhi kesiapsiagan bencana.

\section{DAFTAR PUSTAKA}

Ahayalimuddin, N. (2012) 'Disaster Management: A Study on Knowledge, Attitude and Practice of Emergency Nurse and Community Health Nurse in Selangor', Unpublished Master Dissertation, Universiti Kebangsaan Malaysia.

APCC (2017) Disaster Management Research Roadmap for the ASEAN Region: ASEAN Science- 
Based Disaster Management Platform (ASDMP)

Project. Busan, Republic of Korea, 138 pp.

Arikunto, S. (2010) Prosedur Penelitian. Jakarta: Rineka Citra.

BNPB (2014) Rencana Nasional Penanggulangan Bencana 2015-2019. Jakarta: www.bnpb.go.id.

BNPB (2015a) Kebijakan Strategis BNPB 2015-2019. Jakarta: www.bnpb.go.id.

BNPB (2015b) Rencana Strategis BNPB Tahun 20152019. Jakarta: www.bnpb.go.id.

BNPB (2017) 'Pengetahuan Kebencanaan', in BNPB. Jakarta: www.bnpb.go.id.

BNPB (2018a) Tren Kejadian Bencana 10 tahun terakhir di Indonesia. Jakarta: www.bnpb.go.id.

BNPB (2018b) Tren Kejadian Bencana 10 Tahun Terakhir di Provinsi Nusa Tenggara Barat. Jakarta: www.bnpb.go.id.

Carter, W. N. (2008) Disaster Management Hand Book. Mandaluyong City, Phil.: Asian Development Bank.

CFE-DM (2018) Indonesia Disaster Management Reference Handbook. Center for Excellence in Disaster Management \& Humanitarian Assistance. Available at:

http://reliefweb.int/map/chile/chilelocationmap-2013.

DEPKES RI (2002) 'Pedoman Koordinasi Penanggulangan Bencana di Lapangan'.

DEPKES RI (2007) Pedoman Teknis Penanggulangan Krisis Kesehatan Akibat Bencana.

Diab, M. and Mabrouk, S. (2015) 'The Effects of Guidance Booklet on Knowledge and Attitudes of Nurse Regarding Disaster Preparedness at Hospitals', J Nurs Educ Pract.

Erfandi (2009) Pengetahuan dan Faktor-Faktor yang Mempengaruhi.

Fatoni, Z. (2013) 'Permasalahan Kesehatan Dalam Kondisi Bencana : Peran Petugas Kesehatan dan Partispasi Masyarakat', Jurnal Kependudukan Indonesia, 8(1).

Hammad, K., Arbon, P. and Gebbie, K. (2011) 'Emergency Nurses and Disaster Response: An Exploration of South Australian Emergency Nurses' Knowledge and Perception of Their Roles in Disaster Response', Australasian Emergency Nursing Journal.

Hermawati, D., Hatthakit, U. and Chowalit, A. (2010) 'Nurse's Preparedness of Knowledge and Skills in Caring for Patients Attacked by Tsunami and Its Relating Factors'.

Husna, C. (2012) 'Influencing Factors on Disaster Preparedness in RSUDZA Banda Aceh Cut Husna', Idea Nursing Journal, 3(2).

Khambali, I. (2017) Manajemen Penanggulangan Bencana. 1st edn. Yogyakarta: CV. ANDI OFFSET.

Khan, H., Vasilescu, G. and Khan, A. (2008) 'Disaster Management Cycle - A Theoretical Approach'.

Malayu, S. . H. (2003) Organisasi dan Motivasi Dasar Peningkatan Produktivitas. Jakarta: Bumi Aksara.
Malayu, S. . H. (2007) Manajemen Sumber Daya Manusia. Cetakan 9. Jakarta: PT. Bumi Aksara.

Maulana, H. D. . (2009) Promosi Kesehatan. Jakarta: Penerbit Buku Kedokteran EGC.

Menteri Kesehatan RI (2006) 'Keputusan Menteri Kesehatan RI No.066/MENKES/SK/II/2006 Tentang Pedoman Manajemen Sumber Daya Manusia (SDM) Kesehatan Dalam Penanggulangan Bencana'.

Moabi, R. M. (2008) 'Knowledge, Attitudes and Practices of Health Care Workers Regarding Disaster Preparedness at Johannesburg Hospital In Gauteng Province, South Africa'.

Notoatmodjo, S. (2003) Pendidikan dan Perilaku Kesehatan. Jakarta: Rineka Cipta.

Notoatmodjo, S. (2007) Promosi Kesehatan dan Ilmu Perilaku. Jakarta: Rineka Cipta.

Notoatmodjo, S. (2010) Ilmu Perilaku Kesehatan. Jakarta: Rineka Cipta.

Nursalam (2017) Metodologi Penelitian Ilmu Keperawatan: Pendekatan Praktis Edisi 4. 4th edn. Jakarta: Salemba Medika.

Osman, N. N. S. and Ahayalimuddin, N. (2016) 'Disaster management: Emergency nursing and medical personnel's knowledge, attitude and practices of the East Coast region hospitals of Malaysia', Australasian Emergency Nursing Journal. College of Emergency Nursing Australasia, pp. 1-7. doi: 10.1016/j.aenj.2016.08.001.

Putra, A. et al. (2015) 'Nurses ' Role and Leadership in disaster management at the emergency response', Idea Nursing Journal, 6(1), pp. 25-31.

Rizqillah, A. F. and Suna, J. (2018) 'Indonesian emergency nurses' preparedness to respond to disaster: A descriptive survey', Australasian Emergency Care. College of Emergency Nursing Australasia, pp. 1-5. doi: 10.1016/j.auec.2018.04.001.

Syafar, M. and Frances, M. (2018) 'Disaster preparedness and learning needs among community health nurse coordinators in South Sulawesi Indonesia', Australasian Emergency Care. College of Emergency Nursing Australasia. doi: 10.1016/j.auec.2017.11.002.

Tatuil, S., Mandagi, C. K. F. and Engkeng, S. (2015) 'Kajian Peran Tenaga Kesehatan Dalam Kesiapsiagaan Bencana Banjir di Wilayah Kerja Puskesmas Tuminting Kota Manado', Idea Nursing Journal, pp. 1-8.

UU RI No.24 (2007) Undang-Undang RI Nomor 24 Tahun 2007 Tantang Penanggulangan Bencana.

Wawan, A. and M, D. (2010) Teori \& Pengukuhan Pengetahuan, Sikap dan Perilaku Manusia. Yogyakarta: Nuha Medika. 